\title{
Environmental justice and biospheric egalitarianism: reflecting on a normative-philosophical view of human-nature relationship
}

\author{
Helen Kopnina
}

\begin{abstract}
The recent shift towards the interdisciplinary study of the human-environment relationship is largely driven by environmental justice debates. This article will distinguish four types of environmental justice and link them to questions of neoliberalism and altruism. First, environmental justice seeks to redress inequitable distribution of environmental burdens to vulnerable groups and economically disadvantaged populations. Second, environmental justice highlights the developed and developing countries' unequal exposure to environmental risks and benefits. Third, temporal environmental justice refers to the issues associated with intergenerational justice or concern for future generations of humans. In all three cases, environmental justice entails equitable distribution of burdens and benefits to different nations or social groups. By contrast, ecological justice involves biospheric egalitarianism or justice between species. This article will focus on ecological justice since the rights of non-human species lags behind social justice debates and discuss the implications of including biospheric egalitarianism in environmental justice debates.
\end{abstract}

Keywords: Environmental justice; Ecological justice; Altruism; Biospheric egalitarianism; Environmental ethics; Neoliberalism

\section{Report}

Environmental justice (EJ) refers to equitable distribution of environmental goods among human populations as well as between species (Rhodes 2003; Hornborg 2011). EJ is often seen as a condition when members of disadvantaged, ethnic, minority or other groups suffer disproportionately at the local, regional or national levels from environmental risks or hazards. EJ is also evoked in relation to violations of fundamental human rights as a result of environmental factors. EJ becomes particularly salient considering the scarcity of natural resources, or when group identities are linked to environmental burdens or benefits, or when there is an increased awareness of the dangers that human activities pose to natural environment (Clayton 2000:460).

David Schlosberg (2007) eschews an a priori hierarchy of claimants to justice; instead he considers various

\footnotetext{
Correspondence: h.kopnina@hhs.nl
The Hague University of Applied Science, International Business

Correspondence: h.kopnina@hhs.nl
The Hague University of Applied Science, International Business

Management Studies, Johanna Westerdijkplein 75, 2521 EN Den Haag, The Netherlands
}

models of political deliberation among a plurality of parties, including nonhumans. According to Schlosberg (2007), the theory and practice of EJ necessarily includes distributive conceptions of justice, but must also embrace notions of justice based in recognition, capabilities, and participation and relations between human communities and non-human nature. Schlosberg argues that individual organisms and natural systems are entitled to a fair share of essential goods, to recognition as part of an extended community, to the development and enjoyment of capabilities for what he terms 'flourishing', and to some measure of inclusion in political processes. Schlosberg considers eco-advocates who would represent non-humans in democratic assemblies.

Critics have noted however that Schlosberg insufficiently recognizes the potential for serious conflict among the various dimensions of and claimants to ecological justice (e.g. Cannavó 2008). This article is written in support of Schlosberg's thesis, but also to argue that the recognition of conflict is essential for advancing both social and ecological agendas.

\section{草}


This article aims to explore normative-philosophical and practical implications of including the rights of nonhuman species into EJ. The following sections will address the types of EJ and link them to questions of neoliberalism and altruism. We shall then focus on the role of ecological justice and discuss implications of expanding moral boundaries of EJ to include the nonhuman species.

\section{Types of environmental justice}

The concept of EJ has been classified as four-fold (Kopnina 2010). The first conception refers to inequitable distribution of environmental burdens such as hazardous and polluting industries to vulnerable groups such as ethnic minorities or the economically disadvantaged populations (e.g. Carter 2007). The second conception refers to the developed and developing countries' unequal exposure to environmental risks and benefits, such as the consequences of climate change. This is due in large part to the fact that the poorest people tend to live in the most polluted environments since in the rural areas of the developing world, they have been forced onto marginal areas by the process of enclosure, leading to deforestation, soil erosion, and agricultural failure (Singer and Evans 2013). A related concept is environmental racism, which typically involves placement of economically disadvantaged or minority communities in proximity to environmentally degraded environments (Melosi 1995). Environmental racism includes any policy or practice that negatively affects the living environment of low-income or ethnically marginalized communities at a higher rate than affluent communities (Holifield 2001).

The third aspect of EJ is intergenerational justice, is commonly conceived as justice between present and future generations of human beings. Temporal concepts of EJ a reflect concerns for future generations of humans as their fate may be uncertain due to the present growth and consumption patterns. This conception is largely based on the Brundland report's famous formulation of sustainable development as 'development that meets the needs of the present generations without compromising the ability of future generations to meet their own needs' (WCED 1987). All three types of EJ entail equitable spatial and temporal distribution of burdens and benefits to different nations or social groups (e.g. Elliot 2004).

Fourth, EJ involves the so-called biospheric egalitarianism, which is concerned with other species independent of their instrumental value for humans and refers to justice between human and non-human species (Baxter 2005).

\section{Social vs. ecological justice and the question of neoliberalism}

Different types of EJ are not always complimentary. West and Carrier (2004) have criticised 'spectacular landscapes', transformed into high-end tourist destinations, at the expense of local people's livelihoods. In this view, conservation is a neo-colonial fortress in which Western environmentalism is imposed upon traditional societies. Benjamenson et al (2006) have stated that preservation of biodiversity at the expense of livelihood security and poverty alleviation is "ethically problematic".

Other scholars have asserted that social scientists themselves are influenced by the dominant neoliberal ideology of anthropocentrism (Catton and Dunlap 1978; Callicott 1999; Kopnina 2012c, d; Crist 2012). Also, while initial culpability for environmental problems can be attributed to Western neoliberal economy, persistence of these problems cannot be decoupled from the global rise in population and consumption, both in 'developed' and 'developing' worlds (Cafaro and Crist 2012). What is than "ethically problematic" is that in talking about economic development, defenders of human rights imitate the neoliberal ideology of the dominant political elites.

Neoliberalism is broadly defined as a theory of political economic practices which proposes that human wellbeing can best be advanced by the maximization of entrepreneurial freedoms within an institutional framework characterized by private property rights, individual liberty, free markets and free trade (Harvey 2005:2) Neoliberal ideas also tend to situate environmental concerns within the logic of economic development, through the process of accumulation of skills, technologies and markets targeted at profit maximization.

Critical scholars dispute whether neoliberal and development enterprise is adequate in addressing social and environmental challenges. Hursh and Henderson (2011) reflect that the dominance of neoliberalism is partially due to the fact that the power elites benefit from homogenizing policies propagating the logic of economic growth.

Capitalist industrial development has forced subsistence agriculturists to live in cities, further removing them from nature. Merchant (2006) identifies the Enlightenment as the period when science began to atomize, objectify and dissect nature, foretelling its eventual conception as inert. As more and more cultures are sliding towards a heightened level of anthropocentrism under the influence of complex post-industrial conditions, "with the animals in our laps and our mechanized slaughterhouses, we are less sure of who they are and therefore who we are" (Shepard 1993:289). Presently, the power of corporate elites within neo-liberal states may be influencing government decisions as well as how communities behave and even think. As Casagrande and Peters (2013) argue, power elite discursively manipulate cultural models and cognitive dissonance to maintain power. 
Neoliberal thinkers often ascribe to the 'shallow ecology' view of environment (Naess 2001) where equity in distribution of natural resources takes precedence over concerns about survival of those that constitute these 'resources' (Bakker 2010). Thus, environmental anthropologists have stressed the importance of recognising the indigenous and non-European traditions in valuing nature (Shoreman-Ouimet and Kopnina 2011).

\section{Non-Western perspectives}

The Principles of Ecological Justice from the First People of Color Leadership Conference, UN Declaration on the Rights of Indigenous Peoples, the Indigenous Environmental Network, the Bolivian "rights of Mother Nature" initiative, as well as numerous other declarations on environmental and climate change issues made by indigenous peoples are all examples of representation of non-Western perspectives on EJ.

Anthropologists have noticed that the idea of humans as part of nature is paramount to traditional perception of human-nature relationships. In this view, the understanding of the relationships that bind together all forms of life has been fundamental to the ability of indigenous peoples to live in spiritual and physical harmony with the land, passed on through generations. There are a few intertwined threads that are common in indigenous vision - that nature is of equal moral status as humans, that nature has rights, that species are in kinship relationships with human beings, and that all life is sacred (e.g. Shiva 1993; Weaver 1996; McGregor 2009; Figueroa 2011; Grossman and Parker 2012; Maldonado et al 2013; Kopnina and Shoreman-Ouimet 2011; Kopnina 2013a, 2013b, 2013c, 2012e, 2014).

Preston Hardison (2014) has noted that many indigenous peoples work actively against extinction both for the moral imperative to protect and fulfill their obligations to their non-human brothers and sisters, and because it would harm their own identities and human integrity associated with these relationships. While the master/slave trope might characterize the industrial society relationship to the environment, indigenous peoples characterize relationships between humans and non-humans in a narrative that links reciprocal obligations, in which other species willingly sacrifice themselves to humans if they are treated well and with the proper respect. Their role is to provide for humans, but that is generally taken to be conditional on their treatment.

Chaudhuri (2012), has argued that the narrative of human destructiveness is thus balanced with the narrative with one in which humans can play a healing role. This could be the key to restoring the balance of justice, provided by the indigenous or minority perspectives, to addressing justice between all, human and non-human planetary residents.
In examining multiple levels of meaning that inform Native astronomy and cosmology, Cajete (1994, 2000), a Native American anthropologist of indigenous learning, noted that in many traditional societies the transmission of environmental knowledge is intergenerational. Cajete reflects that unlike the western scientific method, native thinking perceives elements of nature as relational.

\section{Questions and conflicts}

However, there are also criticisms of this view of traditional communities living in harmony with nature. Similar to the representation of the indigenous communities in the film Avatar, non-Western populations are often represented as 'noble savages'. This ideal has given way to realization that local people have human vices like we do (Wagley 1976), and recognition that the indigenous people' are 'rarely isolated from global market forces' (Pountney 2012:215). We need to ask: are these indigenous, non-Western, non-white perspectives not increasingly influenced by global neoliberal vision of the world? Are they not submerging under the dominant perspectives? Are these non-Western perspectives and ways of life strong enough? Considering the world's power hegemonies, and daily increases in human population, in case of conflict between human- environmental interests, will the ethical considerations not automatically weigh toward people? How do traditional values map onto the global patterns of consumption, competition for resources, increasing cultural homogeneity, commercialization of trade, and above all, the spread of neoliberal capitalism?

Also, potential conflict between human and nonhuman interests in non-Western countries is in evidence. Sometimes local communities and non-human interests do correspond and the local communities defend 'their' forests and land against the rapacious actions of logging or mining companies; in other cases they willingly 'sell out' the same 'natural resources' for profit.

Let us examine the case of the Cambodian antideforestation activist Chut Wutty, the Director of environmental watchdog Natural Resource Protection Group (NRPG), who was gunned down by the police while exposing illegal logging activities and land seizures to a journalist. Wutty spent years exposing how Cambodia's corrupt political and business elite have accumulated vast fortunes by selling off the country's land and forests for private gain (The Global Witness 2013).

In Cambodia, land grabs for agricultural development and logging by private firms, such as Economic Land Concessions (ELCs) held by agro-industrial companies by private firms, are common-place (Vrieze and Naren 2012). Conservation International has remained silent on this issue, refusing even to acknowledge the existence of logging. 
Remarkable in this case is the complacency of a number of organizations, including the local authorities but also large conservation organization, in the case that involved illegal commercial logging, opposing any form of protest. Milne (2012) commented that the tragic incident revealed not only the culpability of government officials who abuse their powers to profit from logging, but also the hypocrisy of NGOs like Conservation International, in order to maintain the façade of effectiveness, along with their government and donor relationships.

Another case that had tragic results occurred in January 2013, when over one thousand dolphins were slaughtered by the local people on Solomon Island in the course of a dispute with conservation group, the Earth Island Institute. Accounts of the dispute vary. In 2012, the Solomon Islands banned the live export of dolphins. Before then, the country had been a supplier of live dolphins sold to aquariums in China and Dubai, consequently being paid compensation by the conservation groups to preserve the dolphins (Bennett 2013). The islanders say the Berkeley-based conservation group failed to pay them, as agreed, for stopping the traditional hunt. The Earth Island Institute says the slaughter was the work of a "renegade group" trying to sabotage conservation work, and that community leaders have appropriated the money paid for them (Goldenberg 2013).

What is clear, however, is that a misunderstanding between the villagers and Earth Island has resulted in one of the worst cases of dolphin slaughter in the Solomon Islands for some time, and delivered a huge setback to conservation efforts in a world "hot spot" for the dolphin trade. Some critics have blamed conservationists for not paying local communities enough and causing the slaughter.

\section{Generalising from cases to ethics}

Academics defending economic entitlements of local communities against the efforts of conservationists (e.g. Peluso 1993; Wenzel 2009; McElroy 2013) often fail to address the efficacy of conservation, and the value of non-human lives. For example, anthropologists such as Einarsson (1993) and Kalland (2009) have expressed support of whalers' 'traditional practices', disregarding the fact that most of the whalers are no longer involved in traditional practices but in 'commercial harvesting'. In a similar vein, addressing the two cases above, one of my anthropological colleagues has referred to Chutt Wutty's death as a tragedy, and to the slaughter of dolphins as an unfortunate accident.

Some scholars have argued that there are many ways in which non-human species have been granted a greater degree of moral standing in post-industrial neo-liberal societies than was previously the case. The rise of ethical vegetarianism in the West, the public policies that protect animal rights and the research demonstrating greater similarities between humans and nonhuman animals in cognitive and affective processes all suggests a decrease in the objectification of animals among critical segments of society (Clayton and Brook 2005). Western, developed countries exhibit an increased attention to the importance of green space, and welfare of plants and animals. In her ethnography of the roadkill on American roads, Jane Desmond (2013) reflects that some individuals feel strongly about the subjectivity of the 'collateral damage' of the roadkill.

While there are many testimonials to citizens' concerns for individual animals or plants, there is no consistent discussion about the scale of instrumental use of other species, and proportionally insignificant political representation of advocates for the rights of nonhumans. The scale of human use of animals or plants has increased exponentially with human population growth and increase in consumption (Crist 2013). While the fate of a single rescued dolphin may capture public attention through the media, there is no consistent discussion about millions of species 'harvested' for consumption, or used for medical experiments. Despite guilty feelings of a few individuals, cultural prioritizing of transportation and energy policies place 'mobility' and 'modernity' before animal welfare (Desmond 2013).

Environmental sociologists Dunlap and Catton (1983) argued that there is a fundamental problem with the social science's perception of the place of human beings in the natural world. The authors described the Human Exemptionalist Paradigm (HEP), arguing that irrespective of social scientists' particular theoretical orientation (Marxist, functionalist, symbolic interactionist, etc.) mainstream sociology remained anthropocentric. In HEP, our acts towards animals are judged on the basis of how they affect human beings only and not on how they affect other species (Nibert 2002). View of animals as culturally, socially or economically significant objects sees non-humans as facilitators of technological advancement (e.g. medical experiments or genetic manipulation of plants), as an attribute of cultural practice (e.g. hunting or whaling), or as the objects of economic interest (e.g. animal trade), or symbolic ritual (e.g. animal sacrifice), or collateral damage (e.g. road kill or forest clearings). Given the fact that biodiversity protection is not always contingent with economic interests, and because people can be materially sustained by monocultures (Crist 2003:65), anthropocentric view of non-humans leads to the abandonment of species that are not seen as useful for humanity.

Underlying the range of ethical concerns in regard to 'nature' or other species are issues associated with altruism.

\section{The question of altruism}

The common-place images of EJ we are all familiar with often show poor African farmers or starving Indian 
children. While any type of inter-human discrimination (in terms of exposure to environmental risks and benefits) are recognized as the center of EJ debates, discrimination against individuals within other species or the entire species is not recognized. Many EJ scholars onesidedly focus on the human consequences of environmental injustice while neglecting the issues of justice that arise from our relations with non-human species. Ethical considerations often automatically weigh toward disadvantaged people and not disadvantaged non-human species. This human-focused view is rooted not just in social altruism but in the human supremacist mindset that has enshrined a no-limitation way of life - including no limitation on reproduction, no limitation on consumption and economic growth' (Crist 2013:47).

Conservation psychologists have noted that although a logical distinction can be made between humanistic and biospheric altruism, not all studies find that people make this distinction (Dietz et al 2005). People often treat environmental and ecological altruism as a kind of generalized altruism, rather than as two distinct values (Stern et al 1999). It is thus assumed that those who care about the environment also care about other people. However, most studies find that there is significant difference between human and environment-centered concerns (Dietz et al 2005:358). Studies have indicated that people with ecocentric orientation are more likely to act upon their values in order to protect the environment and that biospheric altruism centered approach leads to sacrifice rather than quality-of-life solutions to environmental problems (Stern et al 1999; Dietz et al 2005).

However, global social altruism is new. Historically and cross-culturally, we can find many examples (some from Western societies as recent as a few decades ago) of how at least some human lives were seen as less important or worth sacrificing. Many indigenous societies' practices, ranging from human sacrifice to infant infanticide to control population have now been declared illegal. Reification of all human life is part and parcel of contemporary development politics, findings its echo's in Western philosophical and religious traditions of enlightenment and individualism, which enshrine anthropocentrism (Taylor 2010). Thus, the overwhelming ethical concern for all humans propagated as the most common-sense moral basis of post-industrial societies seems unprecedented in human history. Related to this unprecedented focus on the value of human life including the lives of unborn children - is the increased concern with resources rather than sentient beings. An unprecedented concern about 'feeding' the entire population of humans is echoed through declarations of the United Nations, as well as Western media and public discourse. Is this a sign that we have moved forward in our moral development? If so, could the next stage of our moral development not be the recognition of the rights of nonhumans? This wide-spread concern about the health, welfare, human rights, etc. of seven billion humans seems to grow in reverse proportion to the increasing disregard for billions of plant and animals species needed daily to satisfy human needs. Many social scientists seemed to have accepted as 'noble' human rights, indigenous rights, fighting poverty, preventing disease, etc. Addressing social and economic 'challenges facing our societies', is very much part of this normative, neoliberal perspective. In this view, animal rights are marginal at best, one of many perspectives.

For those who are unable to participate in our learned academic discussions, it seems that some animals are much more equal than others. Members of the animal liberation and radical environmentalists postulate that exploitation of animals is no different from the extermination of Jews during the Holocaust or slavery (Guither 1998; Liddick 2006). As is often the case with revolutions that lead to change in moral regimes, different conception of justice is often introduced not by the oppressed classes (as they might be too oppressed to be able to struggle) but by the members of elites. As Singer (1989:148) has stressed, our discrimination against animals is similar to social discrimination, requiring similar mental and ethical adjustments as those associated with human liberation movements:

If we wish to avoid being numbered amongst the oppressors, we must be prepared to re-think even our most fundamental attitudes. We need to consider them from the point of view of those most disadvantaged by our attitudes, and the practices that follow from these attitudes. If we can make this unaccustomed mental switch we may discover a pattern in our attitudes and practices that consistently operates so as to benefit one group-usually the one to which we ourselves belong-at the expense of another. In this way we may come to see that there is a case for a new liberation movement. My aim is to advocate that we make this mental switch in respect of our attitudes and practices towards a very large group of beings: members of species other than our own-or, as we popularly though misleadingly call them, animals. In other words, I am urging that we extend to other species the basic principle of equality that most of us recognize should be extended to all members of our own species.

Such human advocates like Arno Naess (2001) and Peter Singer (1989) have proposed the moral basis for preservation of non-human species, others, like Robyn Eckersley (1995; 2004) and Brian Baxter (2005), have linked these rights to debates on justice. 
In A Theory of Ecological Justice, Baxter (2005) links ecology to standard liberal theories of justice, such as those found in the work of Rawls and Barry and defends the claim that all organisms have a claim in justice to a fair share of the planet's environmental resources. In quoting Sir Attenborough's answer to the question whether it mattered if one small species of snail should become extinct due to human activities, especially as no other ecological damage has resulted: 'surely it is sad indeed that our descendants should inherit a natural world that is more impoverished than the one we inherited?' (BBC 2000; quoted in Baxter 2005:9), Baxter doubts the moral validity of this wide-spread argumentation. Baxter argues that at present concerns about future generations of human beings tend to undervalue any argument about the damage done to the snails or any other species:

The possibility of there being any wrong done to the species of snail or to the individual members of the species, receives no mention at all...Apparently, it is only the possible losses to actual and future human beings, whether aesthetic, cultural, scientific, medical, economic, recreational and so forth, that count (Baxter 2005:1).

Baxter argues that the starting point of justice arguments in favour of nature should be nature itself. $\mathrm{He}$ puts forward an argument for accepting that all organisms count, morally-speaking, and not simply those which human beings like or find useful.

\section{Environmental debates}

Biospheric altruism has a different ontology than that of the history of EJ as a movement, which arose in part as a response to (or against) the focus of mainstream environmental advocacy organizations on wilderness and wildlife conservation concerns, when opponents of conservation projects have claimed that indigenous communities were being denied equitable protection against serious environmental risks. The argument that EJ, or environmental ethics more broadly, ought to take into account the value of non-human organisms and systems - has entered environmental ethics debates since the 1970s. Environmental ethic included the ideas that value is mind-independent and exists at several different levels including those of "higher" animals, organisms, species and ecosystems (Jamieson 1997).

That approach has since the 1980 s been subject to cogent critiques from a number of environmental ethicists, questioning the assertion that current human population is THE mechanism behind environmental degradation and disregard for non-human organisms, or, that there is some causal relationship between these (Norton 1984). The recent wave of environmental ethicists criticized the presumed division between either morally limited or fully integrated egalitarianism and outlined many other options (Light 2010). These options included a more robust understanding of justice in terms of obligations to other moral agents, requiring consent, criticizing defenders of non-human species as builders of the straw man argument, reducing the human-centered view to a feeble parody of what a full-throated cry for human justice might entail.

Eco-Marxist scholar Schnaiberg (1980) argues against what he terms Malthusian determinism with the rationale that under larger capitalist economies, human degradation moved to organizationally caused degradation of capitalist political economies and that the global population growth is not to blame. Schnaiberg provided the example of the organized degradation of rainforest areas in which powerful elites push people off the land before it is degraded by organizational means. Schnaiberg argued that environmental damage caused by statepolitical and labor-supported capitalist expansion may cause a decline both in the state's funding as well as worker livelihood, necessitating ecologically benevolent state action, signifying a turn toward ecological modernisation (Mol and Sonnenfeld 2000).

Technological development was proposed as the key to achieving sustainability. It was thus believed that enlightened self-interest, economy and ecology can be favorably combined and that greater wealth will lead to the development of postmaterialistist values (Inglehart 1971). Postmaterialistist values theory assumes that while wealthier societies can 'afford' to care about the environment, the developing countries cannot.

However, empirical evidence of accelerating climate change, habitat destruction, and species extinction all testify to the fact that combined forces of population and consumption growth tend to override any positive gains promised by scientific and technological advancement (Cafaro and Crist 2012). As publications of International Development Research Center suggest, the development paths of industrialised North are not viable, despite of technological and social changes. The rich North is failing to address serious environmental challenges as well as intensified animal exploitation for increasing human consumption, as in the case of CAFO's, intensive farming. Technological advancement does nothing to alter the impulses within the capitalist economic mode of production that inevitably lead to environmental degradation (Foster 2002) and decrease of animal welfare, particularly if left to business as usual (York and Rosa 2003).

This article will not discuss further the differences in environmental ethics, animal liberation, biospheric egalitarianism and related perspectives ${ }^{\mathrm{a}}$. Despite the richness of environmental ethics debates, most biocentric, ecocentric, 
or animal rights supporting authors agree that the urgency of the problem - rapid destruction of habitats, extinction of species, industrial farming - the point of convergence is an extension of the moral consideration to animals or habitats. The golden toad (now extinct) and the Sumatran tiger (critically endangered) do not benefit from the so-called plurality of perspectives that privileges one species only. From a practical point of view, Callicott (1988) has argued for making common cause against a common enemy -the destructive forces at work ravaging the nonhuman world rather 'than to continue squabbling among ourselves'. Jamieson (1997) has also argued that animal liberationists and environmental ethicists share many views, recognising serious threats to both individual animals as well as to environment; because animal liberationists can value nature as a home for sentient beings; and because animal liberationists can embrace environmental values as intensely as environmental ethicists.

At the plenary session of the 17th World Congress of the International Union of Anthropological and Ethnological Sciences, in Manchester in August 2013, the motion 'Justice for people should come before justice for the environment' was debated (http://www.iuaes2013. org/Plenaries.html). Briefly summed up, the main argument for the motion centered around the idea that conservationists are mostly Western elites and that their actions impinge upon cultural practices and economic development of local communities. Supporting the motion, Amita Baviskar and Don Nonini have argued that anthropologists have a duty to uphold human rights and indigenous entitlements against Western environmentalists.

The opponents Helen Kopnina and Veronica Strang have argued that environmentalism is not a Western but a universal phenomenon, and that love of nature is shared by many traditional societies. They agreed with the proponents of the motion that culpability for ecological problems lies largely with corporate and political elites that perpetuate the neoliberal industrial economy and commodification of nature. They have pointed out that 'cultural practices' of most societies have now given way to globalized consumerism. If ecological justice is to be recognized, both nature and the people will benefit as humans and environment are intimately interconnected.

Veronica Strang (2013) reflected:

In a world where the most powerful groups live in wholly unsustainable affluence, it is very difficult to suggest that anyone should be prevented from enjoying the immediate material benefits that these practices allow... However, there remains a thorny question as to whether anyone, advantaged or disadvantaged, has the right to prioritise their own interests to the extent that those of the non-human are deemed expendable. Discourses on justice for people often imply that the most disadvantaged groups should have special rights to redress long-term imbalances... However, if the result is only a short-term gain at the long-term expense of the non-human, this is in itself not a sustainable process for maintaining either social or environmental equity.

After the debate and presentations attending members of the plenary session were asked to vote for or against the motion. Considerable majority of 90 voted against the motion. Most participants were thus convinced that ecological justice needs to be considered as part of EJ. It was recognized that learning from non-Western perspectives, recognizing care, responsibility and interconnectedness could lead to a better stewardship and guardianship of the world in the long-run (e.g. Hardison 2014).

\section{Implications for justice debates}

In a 1972 paper titled "Should Trees Have Standing?" Christopher D. Stone proposed that if corporations are assigned rights, so should natural objects such as trees. The book was a rallying point for the then burgeoning environmental movement, launching a worldwide debate on the basic nature of legal rights that reached the U.S. Supreme Court. Stone (2010) explored the impact his ideas have had on the American courts, the academy, and society as a whole. At the heart of the book is a compelling argument why trees and the environment as a whole should be bestowed with legal rights, so that the voiceless elements in nature are protected against threats of human population growth and increase in consumption.

Perhaps the greatest challenge for all theorists of ecological justice is not working out the finer points of the debate, on which they essentially agree (as most would argue for some form of animal or biospheric rights and recognition of some extent of intrinsic value of all beings, human and non-human), but rather to devise a common strategy allowing those 'in power' (international institutions, policy- makers, consumers, etc.) to recognize the importance of these basic shared values.

While there is a degree of disagreement whether only individuals within the species, entire species or the whole habitats should be valued and to what extent, the crucial point is that for both deep ecologists or animal rights advocates ecological justice needs to transcend anthropocentrism that makes other species subservient to human rights and entitlements. The issue here is the current imbalance between the value of human life in relation to other lives (for example, concerns about being able to 'save lives' through animal testing, or concerns about 'feeding the planet', meaning people only). While human rights are widely acknowledged in neoliberal rhetoric, no such acknowledgement is made in regard to 
animal rights for millions of cattle or chickens slaughtered every day to feed the growing human population, or billions of mice used for scientific experiments, or thousands of acres of forest cleared for the ever-expanding agricultural development.

\section{Reconciliation}

Compassion originating from emotional identification with nature leads one to defend the loved objects that are being violated is common in all cultures (Munro 2001). And here, we can argue, the opportunity for reconciliation lies. Returning to the Cambodian case, it is unlikely that mainstream conservation organizations will ever fulfil the role that Chut Wutty as his life-force and approach as a leader and eco-warrior was truly unique, and this must be honoured and sustained by the Cambodian people (Milne 2012).

In the blog post of Vegans of Color (http://vegansofcolor. wordpress.com/tag/animal-rights/) this common call is heard:

If transition away from automobile culture, towards renewable energies, and towards composting and water recycling are part of the green movement that might buy us all more time on the world as we know it, than veganism - a veganism cognizant of the human and Earth liberation elements of its actualization - also must be part of that same movement. And it has to be about as many of us humans as possible.

Since we pursue those things which materially and otherwise most benefit us, as do all other creatures, then a veganism that appeals to our longevity and the leveling of the balance of power in human societies should theoretically find mass appeal. Veganism in explicit combination with human rights, or veganism plus human liberation, can be understood as Liberation Veganism. Liberation Veganism ... has its obvious ethical elements, ecological arguments, and social justice underpinnings, but as a liberation movement, it can and must include all the social capital of successful trends: propaganda, recipes indigenous to our cultures which veganize palates and minds from the grassroots, and the revolutionary gatherings, rallies and potlucks that find ways to intermix all manner of human rights and liberation issues with the way we eat. Wider application of this 'food for thought' is the idea of justice - and injustice done to the weaker party, be they local impoverished populations or felled trees.

Outside of anthropology, the common problem in the EJ literature is that people of color, people from the developing world, and indigenous peoples' scholarship are often omitted from the EJ literature. Yet, perhaps we could learn from non-Western communities to recognize the short-sightedness as well as the moral deficiency of prioritizing social or economic justice at the expense of the non-humans. These non-Western perspectives teach us that we cannot have justice for people before justice for the environment, because separating these will lead to neither. We need to consider justice more broadly, as something that depends on upholding the simultaneous common good of the human and the non-human (Strang 2013).

\section{Affirmative action}

Without acknowledgement and articulation how some conflicts-especially between humans and non-humanscan become a matter of basic survival, any deliberative, pluralist politics may encounter serious limits (Cannavó 2008). Considering the fact that continuous advocacy and representation is needed to represent non-humans (who will never speak for themselves), we need to push justice debate beyond academic compounds. This might require much more 'affirmative action'. As a prominent anthropologist Eugene Anderson (2014) has remarked: 'Today, with the world ecosystem crashing around us, we are going to have to take stands'. If animal life had been placed on an existential par with human life - or animals have been recognized as subjects of their lives - then their exploitation and that of their homelands would have been rendered morally unfeasible (Crist 2013).

Only after the general public is convinced that normative-philosophical grounds upon which habitat destruction, species extinction, poor treatment of animals and many other practices stand are morally wrong, can we expect any kind of positive change to occur. This change will be profound as it will affect all non-human species: those that we directly depend on (e.g. consumption), use for companionship, recreation and entertainment (e.g. pets, zoo animals, house plants, parks, etc.) potentially depend on (e.g. biodiversity, for example certain medicinal plants for pharmaceutical industry) and those that we do not depend on ('left over' biodiversity). Such a change would imply that a host of issues ranging from biodiversity protection to animal rights will need to be integrated into national laws, the way other forms of human rights and non-discrimination measures are currently integrated within national legal systems.

This implies the need to develop a post-racial, postgender, post-class, undifferentiated humanity so we can develop responsibility for other species. It also implies that EJ framework can provide the solution for environmental conflicts (Müller 2012). If social altruism can be learned, this has significant implications for the role of education in fostering biospheric egalitarianism 
(Kopnina 2012a, b). Returning to Baxter (2005) and Schlosberg (2007), in working out conflicts over justice, various models of political deliberation among a plurality of parties, including nonhumans, need to be further considered. Drawing on both authors' reflection on deliberative democracy and pluralism, the practical promise of his approach to justice needs to be further explored.

\section{Conclusion}

We have distinguished four types of EJ, with the first three types concerned with equitable distribution of environmental burdens and benefits to nations or social groups in space and time. Presently many EJ scholars one-sidedly focus on the human consequences of environmental injustice and neglect the issues of justice that arise from our relations with non-human species.

The urgency of protecting endangered species or the treatment of animals in industrial system of food production is not likely to be adequately addressed in the current paradigm. In line with Schlosberg's thesis, in order to move forward we need to embrace the notions of justice based on recognition, capabilities, and participation in relations between human communities and non-humans. If the non-humans are to be entitled to a fair share of essential goods, and their right to 'flourish' is recognized, the inclusion of non-humans through ecoadvocates within political systems would be the next step.

The implications of embracing biospheric egalitarianism as part of EJ are profound. If concerns about non-human species are to be seriously considered - this will mean a radical revision of existing justice policies. The expansion of the moral sphere is likely to depend on a myriad of socio-cultural 'butterfly effects'.

It may be said in favour of probability of such a shift that there is evidence that anthropocentric value orientation is not universal and that different forms of altruism can be found in all societies. Given the long history of evolution of human ethics, the shift towards inclusion of biospheric egalitarianism within the framework of EJ seems realistic. The same factors that made gender and race equality so 'common-sense' in the neoliberal societies could be responsible for the shift towards new planetary ethics.

The author is hopeful about the possibility of such a shift. Just as one day slavery has become intolerable, perhaps one day the subordination of non-human species will become unacceptable. And what is a day or even a century in the course of human moral history? After all, what we have to gain is the greater harmony between all those who belong to this planet.

\section{Endnote}

${ }^{a}$ Environmental ethics hosts a lot of debates about what type of approach should be used for advancing ecological justice or animal rights. For example, while Peter Singer proposes utilitarian approach to animal rights, Nussbaum and Sunstein (2004) argues that utilitarian approach to animals ignores adaptive preferences, elides the separateness of distinct persons, misidentifies valuable human/non-human emotions, and calculates according to "sum-rankings" rather than inviolable protection of intrinsic entitlements. As the recent developments of the capabilities approach also include the discussion of the wider biosphere, Nussbaum advocates the capabilities approach is a set of political principles as a framework for human obligations towards other species. To this end, the capabilities approach, similar to previous application to the case of women's rights, the notion of justice for non-human species is based on dignity and Aristotelian notions of flourishing. Based on this approach, Nussbaum (2009) advocates including animals and nature in the "frontiers", or the previously marginal fields, into common liberal justice theories. Singer has retorted however that if we define "flourishing" in a biological sense that Nussbaum's use of terms like "flourishing" blends the boundary between facts and values and that Nussbaum owes us an account of which capabilities she thinks important and good, and why (Singer 2002).

Another example of environmental ethics debate is between Callicott (1980, 1999) and Jamieson (1997), based on Callicott's essay 'Triangular Affair' leading to an increasingly acrimonious divorce between individualistic animal welfare ethics and holistic ecocentric ethics'. In this essay Callicott (1980) claimed that environmental ethics and animal liberation are conceptually distinct, and that animal liberation has more in common with conventional morality than with environmental ethics. Jamieson (1997) has argued however that animal liberationists can hold many of the same normative views as environmental ethicists.

\section{Competing interests}

The author declares that she has no competing interests.

\section{Acknowledgements}

This article is inspired by life and work of my father, who was committed both to his family, and science as well as to nature: https://It.tkk.fi/wiki/N.B. Kopnin.

Responsible editor: Thomas Krafft

Received: 14 June 2013 Accepted: 6 March 2014

Published: 28 March 2014

\section{References}

Anderson E (2014) Email to Listeserv Environmental Anthropology (EANTH-L), thread 'Conservation Biology Approach and the Question of Reciprocity', January 29, 2014

Bakker K (2010) The limits of 'neoliberal natures': Debating green neoliberalism. Progr Hum Geogr 34(6):715-735

Baxter B (2005) A Theory of Ecological Justice. Routledge Research in Environmental Politics. Routledge, New York 
Benjamenson TA, Rohde R, Sjaastad EP, Wisborg P, Lebert T (2006) Land reform, range ecology, and carrying capacities in Namaqualand, South Africa. Ann Assoc Am Geogr 96(3):524-540

Bennett S (2013) 900 dolphins slaughtered in the Solomon Islands. X-Ray Mag, January 30. On-line: http://www.xray-mag.com/content/900-dolphins-slaughtered-solomon-islands-0. Accessed July 20, 2013

Cafaro P, Crist E (2012) Human population growth as if the rest of life mattered. In: Cafaro P, Crist E (ed) Life on the Brink: Environmentalists confront Overpopulation. University of Georgia Press, Athens, GA, pp 141-153

Cajete G (1994) Look to the Mountain. An Ecology of Indigenous Education. Kiwaki Press, Skyland

Cajete G (2000) Native Science: Natural Laws of Interdependence. Clearlight Publishers, Santa Fe, NM

Callicott JB (1980) Animal Liberation: A Triangular Affair. Environ Ethics 2:311-328

Callicott JB (1988) Animal Liberation and Environmental Ethics: Back together Again. http://digitalcommons.calpoly.edu/cgi/viewcontent.cgi? article $=1703 \&$ context $=$ bts

Callicott JB (1999) Moral Monism in Environmental Ethics Defended. In: Beyond the Land Ethic: More Essays in Environmental Philosophy. State University of New York Press, Albany, pp 171-183

Cannavó PF (2008) Defining Environmental Justice: Theories, Movements, and Nature by David Schlosberg. Ethics Polit Aff. Available on-line http://www. ethicsandinternationalaffairs.org/2008/defining-environmental-justice-theoriesmovements-and-nature-by-david-schlosberg/

Carter N (2007) The Politics of the Environment: Ideas, Activism, Policy. Cambridge University Press, New York

Casagrande D, Peters C (2013) Eco-myopia Meets the Longue Durée: An Information Ecology of the Increasingly Arid Southwestern U.S.A. In: Kopnina H, Shoreman-Ouimet E (ed) Environmental Anthropology: Future Directions. Routledge, New York and Oxford, pp 97-144

Catton W, Dunlap R (1978) Environmental sociology: A new paradigm. The American Sociologist 13:41-49

Chaudhuri T (2012) Learning to Protect: Environmental Education in a South Indian Tiger Reserve. In: Kopnina H (ed) Anthropology of Environmental Education. Nova, New York, pp 87-113

Clayton S (2000) Models of justice in the environmental debate. J Soc Issues 56(3):459-474

Clayton S, Brook A (2005) Can psychology help save the world? A model for conservation psychology. Analyses of Social Issues and Public Policy 5(1):87-102

Crist E (2003) Limits-to-growth and the biodiversity crisis. Wild Earth, Spring, pp 62-65

Crist E (2012) Abundant Earth and Population. In: Cafaro P, Crist E (ed) Life on the Brink: Environmentalists confront Overpopulation. University of Georgia Press, pp 141-153

Crist E (2013) Ecocide and the extinction of animal minds. In: Bekoff M (ed) Ignoring Nature No More: The Case for Compassionate Conservation. Chicago University Press, Chicago, pp 45-53. http://press.uchicago.edu/ucp/ books/book/chicago/l/bo14398472.html

Desmond J (2013) Requiem for Roadkill: Death and Denial on America's Roads. In: Kopnina H, Shoreman-Ouimet E (ed) Environmental Anthropology: Future Trends. Routledge, New York and Oxford, pp 46-58

Dietz T, Fitzgerald A, Shwom R (2005) Environnemental Values. Annu Rev Environ Resour 30:335-372

Dunlap R, Catton W (1983) What environmental sociologists have in common (Whether concerned with 'built' or 'natural' environments). Socio Inq 53:113-135

Eckersley R (1995) Liberal democracy and the rights of nature: The struggle for inclusion. Environ Polit 4(4):169-198

Eckersley R (2004) The Green State. Rethinking Democracy and Sovereignty. London, MIT Press

Einarsson N (1993) All animals are equal but some are cetaceans: Conservation and culture conflict. In: Milton K (ed) Environmentalism: The View From Anthropology. Routledge, New York, pp 73-84

Elliot L (2004) The Global Politics of the Environment. Palgrave Macmillan, New York. EPA Environmental Justice Program and Civil Rights http://www.epa. gov/region1/ej/

Figueroa RM (2011) Indigenous Peoples and Cultural Losses. In: Dryzek JS, Norgaard RB, Schlosberg D (ed) The Oxford Handbook of Climate Change and Society. Oxford University Press, Oxford, UK, pp 232-250

Foster JB (2002) Ecology Against Capitalism. Monthly Review Press, New York
Global Witness (2013) Cambodia marks 1 year anniversary of Chut Wutty's murder. April 26. http://www.globalwitness.org/library/cambodia-marks-1year-anniversary-chut-wutty\%E2\%80\%99s-murder. Accessed July 20, 2013

Goldenberg S (2013) Solomon Islands villagers kill 900 dolphins in conservation dispute. Guardian, January 24. http://www.guardian.co.uk/environment/2013/ jan/24/solomon-islands-villagers-kill-900-dolphins

Grossman Z, Parker A (2012) Asserting Native Resilience: Pacific Rim Indigenous Nations Face the Climate Crisis. Oregon State University Press, Oregon. http://osupress.oregonstate.edu/book/asserting-native-resilience

Guither HD (1998) Animal Rights: History and Scope of a Radical Social Movement. Southern Illinois University Press, Carbondale, IL

Hardison P (2014) E-mail on Listserv of Environmental Anthropology on January 8, 2014

Harvey D (2005) A brief history of neoliberalism. Oxford University Press, New York, NY

Holifield R (2001) Defining environmental justice and environmental racism. Urban Geogr 22(1):78-90

Hornborg A (2011) Global Ecology and Unequal Exchange: Fetishism in a Zero-Sum World. Routledge, London

Hursh D, Henderson J (2011) Contesting global neoliberalism and creating alternative futures. Discourse 32(2):171-185

Inglehart R (1971) The Silent Revolution in Post-Industrial Societies. Am Polit Sci Rev 65:991-1017

Jamieson D (1997) Animal liberation is an environmental ethic. Available on-line http://www.acad.carleton.edu/curricular/ENTS/faculty/dale/dale_animal.html

Kalland A (2009) Unveiling the Whale: Discourses on whales and whaling. Studies in Environmental Anthropology and Ethnobiology Series. Berghahn Books, New York

Kopnina H (2010) Educating for Environmental Justice. In: Robbins P, Newman J, Golson JG (ed) SAGE Green Education Series. Green Education, vol 7. Sage, Thousand Oaks, CA, pp 128-130

Kopnina H (2012a) In: Kopnina H (ed) Anthropology of Environmental Education. Nova, New York

Kopnina H (2012b) Education for Sustainable Development (ESD): The turn away from 'environment' in environmental education? Environ Educ Res 18(5):699-717

Kopnina H (2012c) Towards Conservational Anthropology: Addressing anthropocentric bias in anthropology. Dialectical Anthropology 36(1):127-146

Kopnina H (2012d) Re-Examining Culture/Conservation Conflict: the view of anthropology of conservation through the lens of environmental ethics. J Integr Environ Sci 9(1):9-25

Kopnina H (2012e) The Lorax Complex: Deep ecology, Ecocentrism and Exclusion. J Integr Environ Sci 9(4):235-254

Kopnina H (2013a) Evaluating Education for Sustainable Development (ESD): Using Ecocentric and Anthropocentric Attitudes toward the Sustainable Development (EAATSD) scale. Environ Dev Sustain 15(3):607-623

Kopnina H (2013b) Requiem for the weeds: Reflections in Amsterdam city park. Sustain Cities Soc 9:10-14

Kopnina H (2013c) Schooling the World: Exploring the critical course on sustainable development through an anthropological lens. Int J Educ Res $62: 220-228$

Kopnina H (2013d) Forsaking Nature? Contesting 'Biodiversity' Through Competing Discourses of Sustainability. J Educ Sustain Dev 7(1):47-59

Kopnina H (2014) Christmas tale of (un)sustainability: reflecting on consumption and environmental awareness on the streets of Amsterdam. Sustain Cities Soc 10:65-71

Kopnina H, Shoreman-Ouimet E (eds) (2011) Environmental Anthropology Today. Routledge, New York

Liddick DR (2006) Eco-Terrorism: Radical Environmental and Animal Liberation Movements. Praeger Publishers, CT

Light A (2010) Methodological Pragmatism, Pluralism, and Environmental Ethics. In: Keller D (ed) Environmental Ethics: The Big Questions. Blackwell Publishers, Oxford

Maldonado JK, Pandya RE, Colombi BJ (2013) Climate Change and Indigenous Peoples in the United States: Impacts, Experiences, and Actions. Clim Change 120:509-682

McElroy A (2013) Sedna's Children: Inuit Elders' Perceptions of Climate Change and Food Security. In: Kopnina H, Shoreman-Ouimet E (ed) Environmental Anthropology: Future Trends. Routledge, New York and Oxford, pp 145-171

McGregor D (2009) Honouring Our Relations: An Anishnaabe Perspective on Environmental Justice. In: Agyeman J, Cole P, Haluza-Delay R (ed) Speaking 
for Ourselves: Environmental Justice in Canada. University of British Columbia Press, Vancouver, BC, Canada, pp 27-41

Melosi M (1995) Equity, eco-racism and environmental history. Environ Hist Rev 19(3):1-16

Merchant C (2006) The Scientific Revolution and The Death of Nature. Isis 97:513-533

Milne S (2012) Chut Wutty: Tragic casualty of Cambodia's dirty war to save forests. http://asiapacific.anu.edu.au/newmandala/2012/04/30/chut-wuttytragic-casualty-of-cambodia\%E2\%80\%99s-dirty-war-to-save-forests/

Mol APJ, Sonnenfeld DA (2000) Ecological Modernisation around the World: Perspectives and Critical Debates. Routledge, London and Portland

Müller MM (2012) Justice as a Framework for the Solution of Environmental Conflicts. In: Kals E, Maes J (ed) Justice and Conflicts: Theoretical and Empirical Contributions. Springer, New York, pp 239-250

Munro L (2001) Compassionate Beasts. Praeger, Westport, CT

Naess A (2001) In: Rothenberg D (ed) Ecology, Community, and Lifestyle: Outline of an Ecosophy. Cambridge University Press, Cambridge

Nibert D (2002) Animal Rights, Human Rights: Entanglements of Oppression and Liberation. Rowman and Littlefield, New York

Norton B (1984) Environmental Ethics and weak anthropocentrism. Environ Ethics $6: 2$

Nussbaum M (2009) Frontiers of Justice: Disability, Nationality. Harvard University Press, Cambridge, MA, Species Membership

Nussbaum M, Sunstein C (ed) (2004) Animal Rights. Oxford University Press, New York, pp 299-320

Peluso N (1993) Coercing conservation: The politics of state resource control. Glob Environ Chang 3:199-217

Pountney J (2012) Review of Kalland, Unveiling the whale. Durh Anthropol J 18(1):215-217

Rhodes EL (2003) Environmental Justice in America. Indiana University Press, Bloomington, IN

Schlosberg D (2007) Defining Environmental Justice: Theories, Movements, and Nature. Oxford University Press, Oxford

Schnaiberg A (1980) The Environment: From Surplus to Scarcity. Oxford University Press, New York

Shepard P (1993) On animal friends. In: Kellert SR, Wilson EO (ed) The Biophilia Hypothesis. Island Press, Washington, pp 275-300

Shiva V (1993) Monocultures of the Mind: Biodiversity, Biotechnology and Agriculture. Zed Press, New Delhi

Shoreman-Ouimet E, Kopnina H (2011) Introduction: Environmental Anthropology Yesterday and Today. In: Kopnina H, Shoreman-Ouimet E (ed) Environmental Anthropology Today. Routledge, New York and Oxford, pp 1-35

Singer P (1989) All Animals are equal. In: Regan T, Singer P (ed) Animal Rights and Human Obligations, New Jersey, pp 148-182

Singer P (2002) Reply to Martha Nussbaum, 'Justice for Non-Human Animals', The Tanner Lectures on Human Values, November 13. http://www.utilitarianism. net/singer/by/20021113.htm

Singer M, Evans JM (2013) Water Wary: Understandings and Concerns about Water and Health among the Rural Poor of Louisiana. In: Kopnina $\mathrm{H}_{\text {, }}$ Shoreman-Ouimet E (ed) Environmental Anthropology: Future Trends. Routledge, New York and Oxford, pp 172-187

Stern PC, Dietz T, Abel T, Guagnano GA, Kalof L (1999) A social psychological theory of support for social movements: the case of environmentalism. Hum Ecol Rev 6:81-97

Stone CD (1972) Should Trees Have Standing-Toward Legal Rights for Natural Objects. South Calif Law Rev 45:450-487

Stone CD (2010) Should Trees Have Standing? Law, Morality, and the Environment. Oxford University Press, Oxford

Strang V (2013) Notes for plenary debate. World Anthropology Congress. ASA-IUAES conference, Manchester, 5-10 th August 2013. Motion: 'Justice for people must come before justice for the environment'. http://www.youtube $\mathrm{com} /$ watch? $\mathrm{v}=\mathrm{oldnYTYMx}-\mathrm{k}$

Taylor BR (2010) Dark Green Religion: Nature Spirituality and the Planetary Future. University of California Press, Berkeley

Vrieze P, Naren K (2012) SOLD: In the race to exploit Cambodia's forests new maps reveal the rapid spread of plantations and mining across the country. The Cambodia Daily:4-11

Wagley C (1976) [1953] Amazon town. Oxford University Press, New York
WCED (1987) Brundtland Report Our Common Future: The World Commission on Environment and Development, United Nations World Commission on Environment and Development

Weaver J (1996) Defending mother earth: Native American perspectives on environmental justice. Orbis Books, Maryknoll, NY

Wenzel GW (2009) Canadian Inuit subsistence and ecological instability - if the climate changes, must the Inuit? Polar Res 28(1):89-99

West P, Carrier JG (2004) Getting Away from it all? Ecotourism and Authenticity. Curr Anthropol 45(4):483-498

York R, Rosa EA (2003) Key challenges to ecological modernization theory. Organ Environ 16(3):273-288

doi:10.1186/2194-6434-1-8

Cite this article as: Kopnina: Environmental justice and biospheric

egalitarianism: reflecting on a normative-philosophical view of human-nature relationship. Earth Perspectives 2014 1:8.

\section{Submit your manuscript to a SpringerOpen ${ }^{\circ}$ journal and benefit from:}

- Convenient online submission

- Rigorous peer review

- Immediate publication on acceptance

- Open access: articles freely available online

- High visibility within the field

- Retaining the copyright to your article

Submit your next manuscript at springeropen.com 